\title{
Mitochondrial DNA Diversity in Three Sudanese Groat Breeds
}

\author{
Elsura A. Sanhory ${ }^{1,2 *}$, Rania S. Giha1, Zarroug H. Ebrahim², Mohamed Tag Eldin², \\ Nahid A. Gornas ${ }^{1}$ \\ ${ }^{1}$ Unit of Molecular Biology and Immunology, Central Laboratory, Ministry of Science and Communication, \\ Khartoum, Sudan \\ ${ }^{2}$ Faculty of Animal Production, Sudan University, Khartoum, Sudan \\ Email: ngornas@hotmail.com
}

Received 5 January 2014; revised 7 February 2014; accepted 13 February 2014

Copyright (C) 2014 by authors and OALib.

This work is licensed under the Creative Commons Attribution International License (CC BY).

http://creativecommons.org/licenses/by/4.0/

(c) (i) Open Access

\section{Abstract}

This study was conducted on 45 heads (15 of each breed) of three Sudanese domestic goat breeds (Desert goat, Nubian goat and Taggar goat) to pursue complete mitochondrial DNA analysis using PCR-RFLP method to detect the mitochondrial DNA diversity of two mit-DNA haplogroups, lineage $A$ and lineage $D$. The results revealed that most individuals of the three breeds belonged to lineage A with frequencies 0.2 of Desert goats, 0.6 of Nubian goats and 0.6 of Tagar goats. Some of the individuals belonged to modified lineage $A$ with frequencies 0.2 of Desert goats, 0.2 of Nubian goats and 0.2 of Tagar goats; no individual of each belonged to lineage $D$. In conclusion, the appearance of individuals that belonged to modified lineage $A$ in the different goat breeds might be due to mutation resulted from insertion or deletion of events and might a criterion of the Sudanese indigenous goat breeds. However this suggestion needs more confirmative analysis.

\section{Keywords}

Sudanese Goat; Mit-DNA Haplogroups; PCR-RFLP Method; Maternal Lineages

\section{Introduction}

Goats are very genetic valuable resource that is suited for low-input in agricultural production system. They require low input and are easy to manage which makes them suitable for the resource for poor rural households, despite their multiple role and economic importance [1]. In the Sudan Goats are a neglected animal despite the fact that they play a very important role in the rural economy. They live mostly on grazing poor natural pastures

${ }^{*}$ Corresponding author. 
in arid and semi arid areas with no supplementary feeding. They live as scavengers in the streets of towns and cities requiring minimum care and attention despite the fact that they provide many poor urban and rural families with milk and meat [2]. A goat occupies the third position in terms of population size among ruminants in the country [3]. The main breeds in the Sudan are Sudan Nubian, Sudan Desert, Nilotic and Sudan Mountain goat (Taggar) [4]. Goats play an important role in the livelihood of wide sector in Sudanese community. The A.O.A.D (2001) [5] estimated the goat population of Sudan to be (42 million) heads. Main dairy goat breed in the Sudan is the Sudanese Nubian goat, forming about $46 \%$ of goat population. It is widely distributed north of $12^{\circ} \mathrm{N}$ mainly in the riverain environments [6]. Phenotypically it is allied to Egyptian Zariabi, Eriterian Shokri and Syrian Damascus [7]. Sudanese desert goats are mainly found in Western region of the Sudan which including Dar-fur and Kordofan states. Desert goats are mainly raised for meat production especially in rural areas, and they also provide milk for family needs. Body weight gain expresses how the animal utilizes its feed in term of growth rate [8]. The Sudanese mountain goat called Tagar goat, are kept primarily for meat production, generally raised by poor farmers and distressed women, and are widely distributed in many parts of the Sudan and they are concentrated in Nuba mountain of Southern Kordofan [9], and they also added that Their importance comes from the fact that they have a wide range of adaptability and high ability to survive and produce in harsh conditions.

The origins of domestic goats remain uncertain and controversial, but archaeological evidence suggests that they were probably first domesticated in the Fertile Crescent region of the Near East $\approx 10,000$ years ago [10][12]. In the fields of domestication history and phylogeography, mitochondrial DNA (mtDNA) has been one of the most preferred markers since it has some advantages such as capacity to demonstrate geographic distribution of species, higher evolutionary rate compared to genomic DNA, maternal Inheritance and absence of recombination [13]. These maternal markers have been instrumental in identifying wild ancestors, localizing domestication centers and reconstructing colonization and trading routes [14] [15]. Mitochondrial DNA sequencing has been used to explain the origins of many modern domestic livestock species. The existence of multiple mtDNA lineages and their mixing within breeds could be due to multiple domestication events or to introgression between domestic and wild species. Mitochondrial sequencing has been used to elucidate the complexity and origins of many modern domestic livestock species, leading to a general theme of multiple maternal lineages. Recent studies of pigs [16] and goats [17] [18], both thought to have origins in the Fertile Crescent, have reveal additional maternal clades. The main haplogroups A and B are both found in Asia, while B dominates in Europe. Haplogroup C has been found in Portugal, Turkey, the Caucasus, and China [19], whereas haplogroup D, present in Rumanian Karachai and Caucasian animals. Mitochondrial DNA studies on domestic goats identified at least four major mtDNA lineages. Lineage $\mathrm{A}$ is the most diverse and widely distributed across all continents. Lineage B is confined to eastern and southern Asia, including Mongolia, Laos, Malaysia, Pakistan and India. Lineage C is present in low frequencies in Mongolia, Switzerland, Slovenia, Pakistan and India. Finally, lineage $\mathrm{D}$ is rare and only observed in Pakistani and Indian local goats. The time since divergence among these four lineages (more than 200,000 years ago) far predated the time of domestication around 10,000 years ago [20] [21]. Thus, A and C haplogroups have a worldwide distribution although B is mostly present in Asia. Some genetic structure is suspected however at a more restricted geographical scale [22] and some haplogroups, such as $\mathrm{G}$ and F, are now restricted to small regions Middle-East [23] and Sicily [18] respectively.

\section{Materials and Methods}

\subsection{Animal Samples}

Blood samples from forty five Sudanese goats of three different breeds were used in this study. They were obtained from three different regions of Sudan, fifteen Desert goats (Figure 1) were brought from North Kordofan state, fifteen head of Nubian goats (Figure 2) were brought from River Nile state, and fifteen Tagger goats (Figure 3) were brought from Southern Kordofan state.

\subsection{Amplification, Purification of DNA}

2 - $5 \mathrm{ml}$ of blood was collected from external jugular vein using sterile syringes and tubes containing EDTA as an anticoagulant. The samples were collected at random, irrespective of age and sex for each breed group. The DNA extraction was carried out at the Central Laboratory, Ministry of Science and Technology, Khartoum, Sudan. The technique used was the Modified Guanidine Chloride protocol as follows: After blood sample thawing 


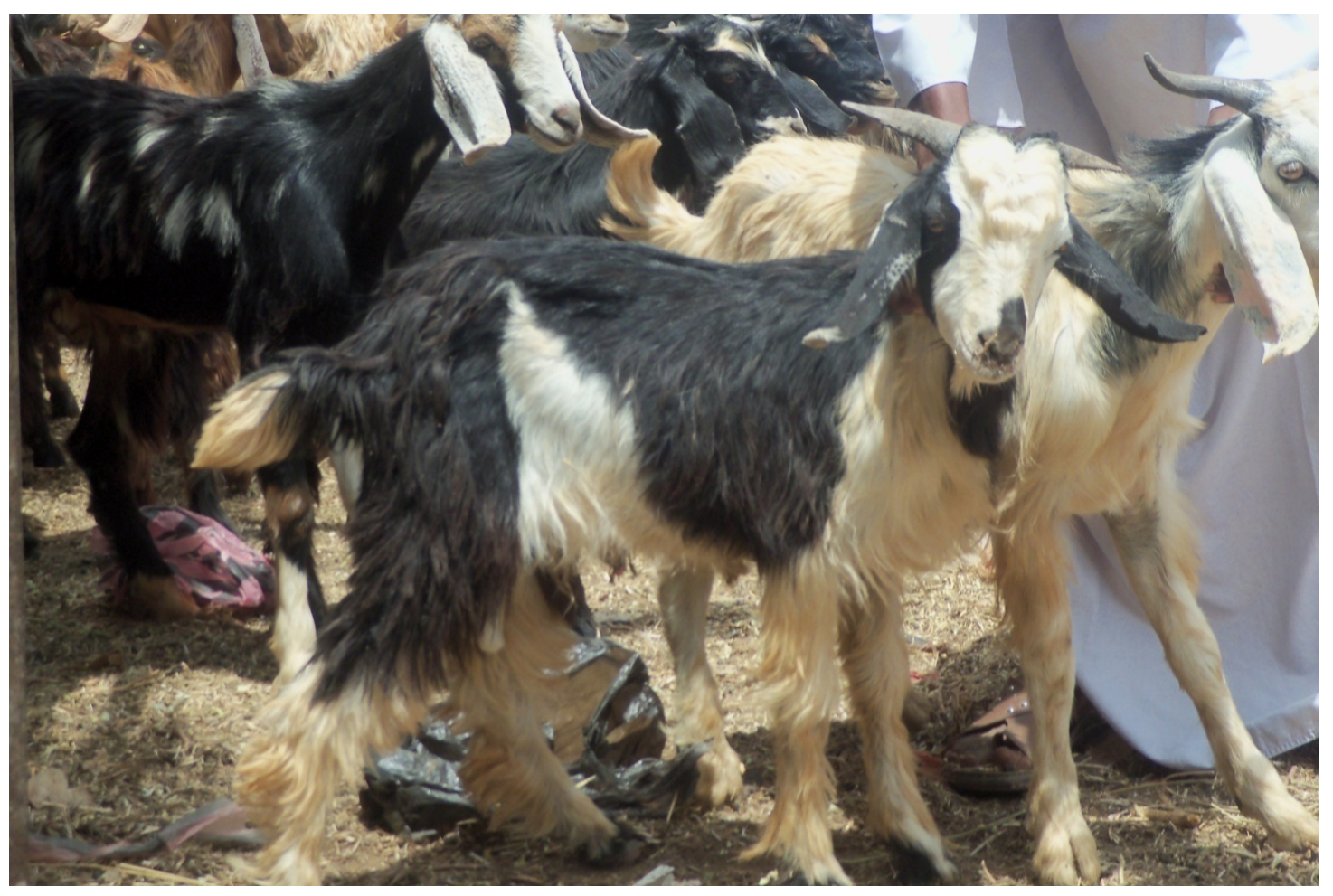

Figure 1. A photograph of Desert goat.

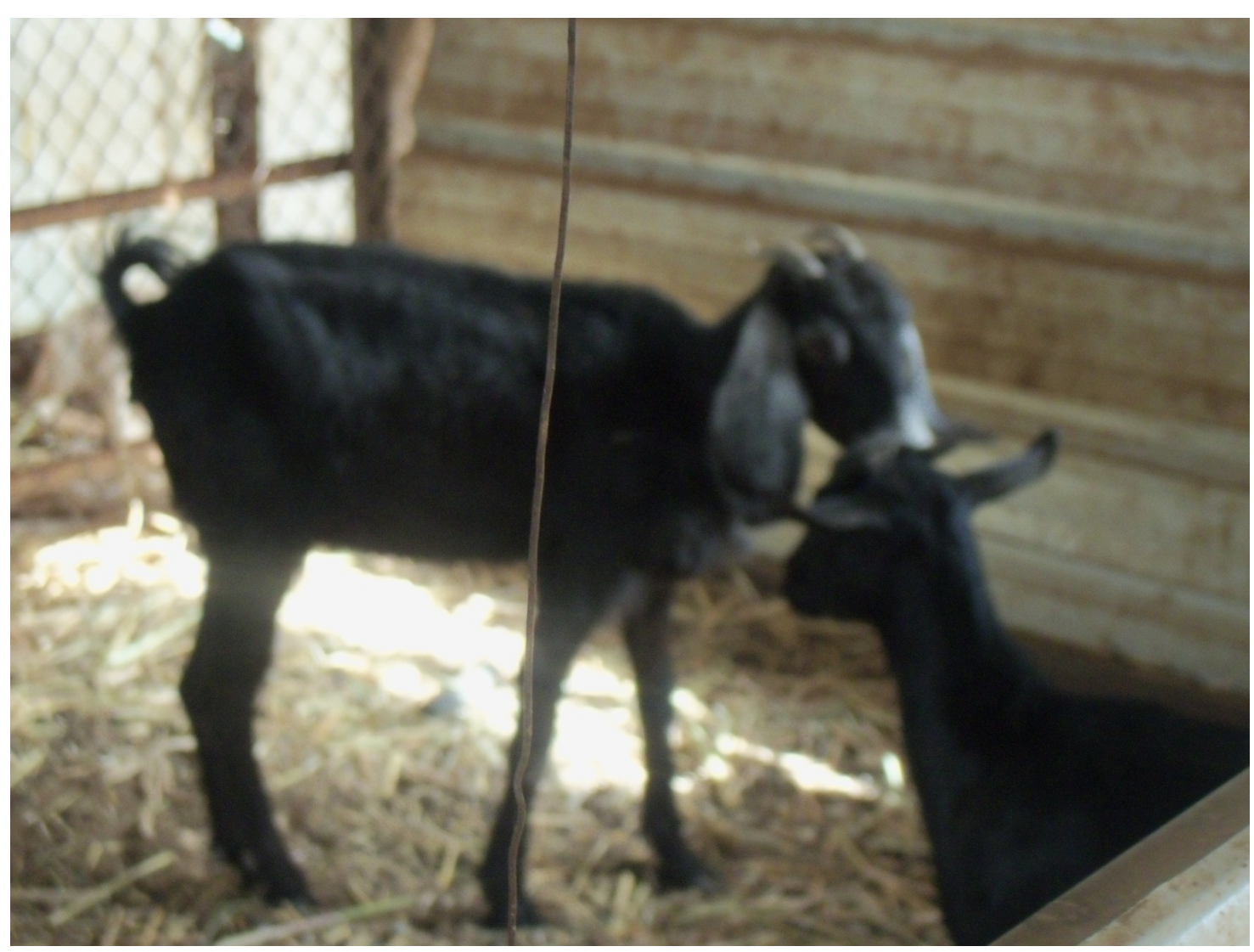

Figure 2. A photograph of Nubian goat. 


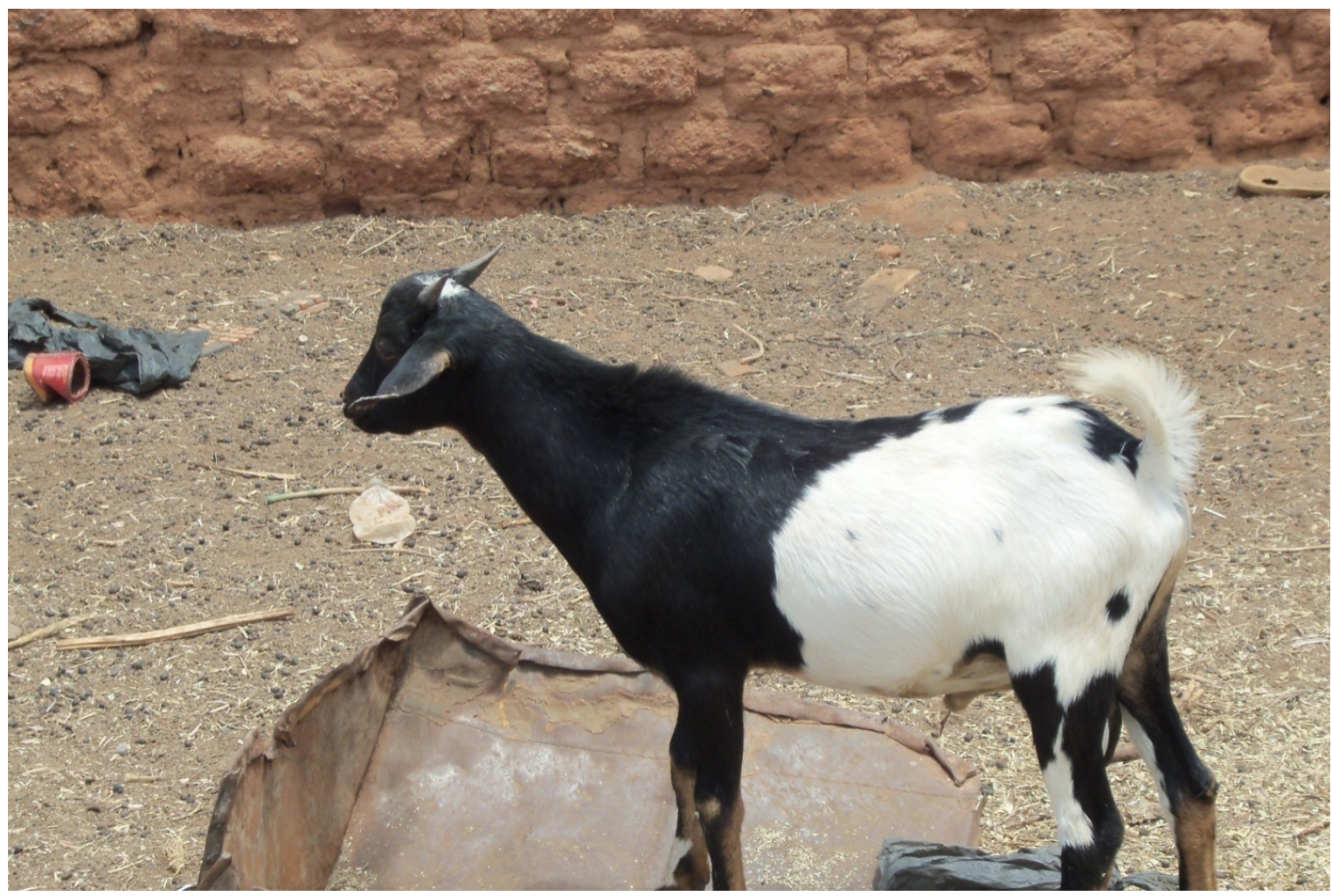

Figure 3. A photograph of Tagar goat.

to room temperature, only $3 \mathrm{ml}$ of blood was taken to falcon tube to which $10 \mathrm{ml}$ of red cell lyses buffer were added, the mixture was mixed with vortex for 1 minute and then by centrifugation for 15 min for 6000 rounds per minute, then the solution was discarded, this step was repeated until a clear pellets of white blood cells were obtained. then $800 \mu \mathrm{m}$ of white cell lyses buffer and $300 \mu \mathrm{m}$ ammonium acetate and $1 \mathrm{ml}$ of Guanidine chloride were added to the pellets and then mixed with vortex, then $10 \mu \mathrm{m}$ of proteinase $\mathrm{k}$ was added and the mixture was incubated at $37^{\circ} \mathrm{C}$ overnight. And the tubes were taken out of the incubator and were cooled to the room temperature; $2 \mathrm{ml}$ of pre-chilled chloroform were transferred to the samples to precipitate the white blood cells and protein. Then the mixtures were mixed with vortex for 1 to 2 minutes and then with centrifugation for 10 minutes at 6000 rounds per minute. On step 7 the upper layers were collected into new labeled falcon tubes, then $10 \mathrm{ml}$ of cold absolute ethanol were added. The mixture was mixed with vortex and kept at $-20^{\circ} \mathrm{C}$ for 2 hours. Then the mixture was taken out and mixed with centrifugation for 10 minutes at 6000 rounds per minute, then the supernatants were drained carefully and the tubes were inverted on tissue paper for 5 minutes. The pellets were washed with $4 \mathrm{ml}$ of $70 \%$ ethanol. The mixture was mixed with centrifugation for 15 minutes at 3000 rounds per minute, the supernatants were powered off and the pellets were allowed to dry overnight. Then the pellets were suspended in $200 \mu \mathrm{m}$ of D.D water. Finally the DNAS were a liquated in stock solution and stored at $-20^{\circ} \mathrm{C}$ in Eppendorf tubes. Both Gel-doc 2000 (Bio-Rad) and agarose gel (75\%) were used for DNA quality definition.

\subsection{PCR Method}

According to Sultana et al. (2003) [24] Polymerase chain reaction (PCR) was used to amplify the complete Mitochondrial DNA (30 of DNA were selected, 10 for each breed) PCR reactions were carried out in $25 \mu$ reaction (for each sample) containing $5 \mu \mathrm{l}$ of master mix (iNtRoN Biotechnology, Inc., Korea), $0.75 \mu \mathrm{l}$ of each primer, $1.20 \mu \mathrm{l} \mathrm{DNA}$, and $17.30 \mu \mathrm{l}$ distilled water. PCR 35 cycles for $3 \mathrm{hr}$, hot start $94 \mathrm{c}$ for $5 \mathrm{~min}$ amplifications were performed using the following conditions: denaturation at $91^{\circ} \mathrm{C}$ for $1 \mathrm{~min}$, annealing at $58^{\circ} \mathrm{C}$ for $1 \mathrm{~min}$, and extension at $72^{\circ} \mathrm{C}$ for $1.5 \mathrm{~min}$. A final extension at $72^{\circ} \mathrm{C}$ for $10 \mathrm{~min}$ was performed to completely extend the amplified product by using. The sequencing primers used in this study are mentioned below. 


\subsection{RFLP Method}

PCR product were digested with restriction enzyme NlaIII (New England BioLabs, MA, USA), at incubation temperature 37c for 3 hr (RFLP) [24].

\subsection{Mt-Lineage Typing}

Mitochondrial-linage typing was performed by using PCR-RFLP methods developed in this study for the thirty animals. The primer set used was (forward: 5'CCTCACTATCAGCACCCAAAGC3') and (reverse: 3'CTGATGTACGTGCTTAATAT GC-5') [24] was employed to amplify a 497 bp segment of the D-loop and digested with NlaIII (New England BioLabs, MA, USA). Products were run on 2.5\% agarose gel. Band patterns for the two mt-lineag, One representative from each mt-lineage type base where the restriction enzyme Nal111 (Hin 111) 'Work at 5'. CATG...3', 3'...G T A C...5' and must cut the original band lineage (PCR product with length 497 bp) into, 69 bp, 172 bp, 256 bp for lineage A and 172 bp and 325 bp for lineage D.

\section{Results}

The blood samples which were collected from forty five individuals, fifteen samples for each breed, were analyzed for DNA extraction. After detection of DNA, some samples appeared without DNA products in the different animal breeds: desert goat (five), Nubian goats (three) and Taggar goats (one). For the PCR analysis the best DNA bands were selected, ten for each breed (Figure 4). Some samples of PCR products when digested with the target restriction enzyme were lost. These samples appeared with protein indicated by detection of DNA bands with smears during DNA extraction.

The final results of the experiment in this study of Mt-lineage A and D in 30 individuals of the three Sudanese goat breeds point out a tendency for a higher similarity between these breeds that all of them belong to lineage A and there is no one belongs to lineage D (Figure 5).

According to the PCR product in (Figure 4) 9 the length of original band is 497 bp which was digested with the restriction enzyme into four bands as follows:

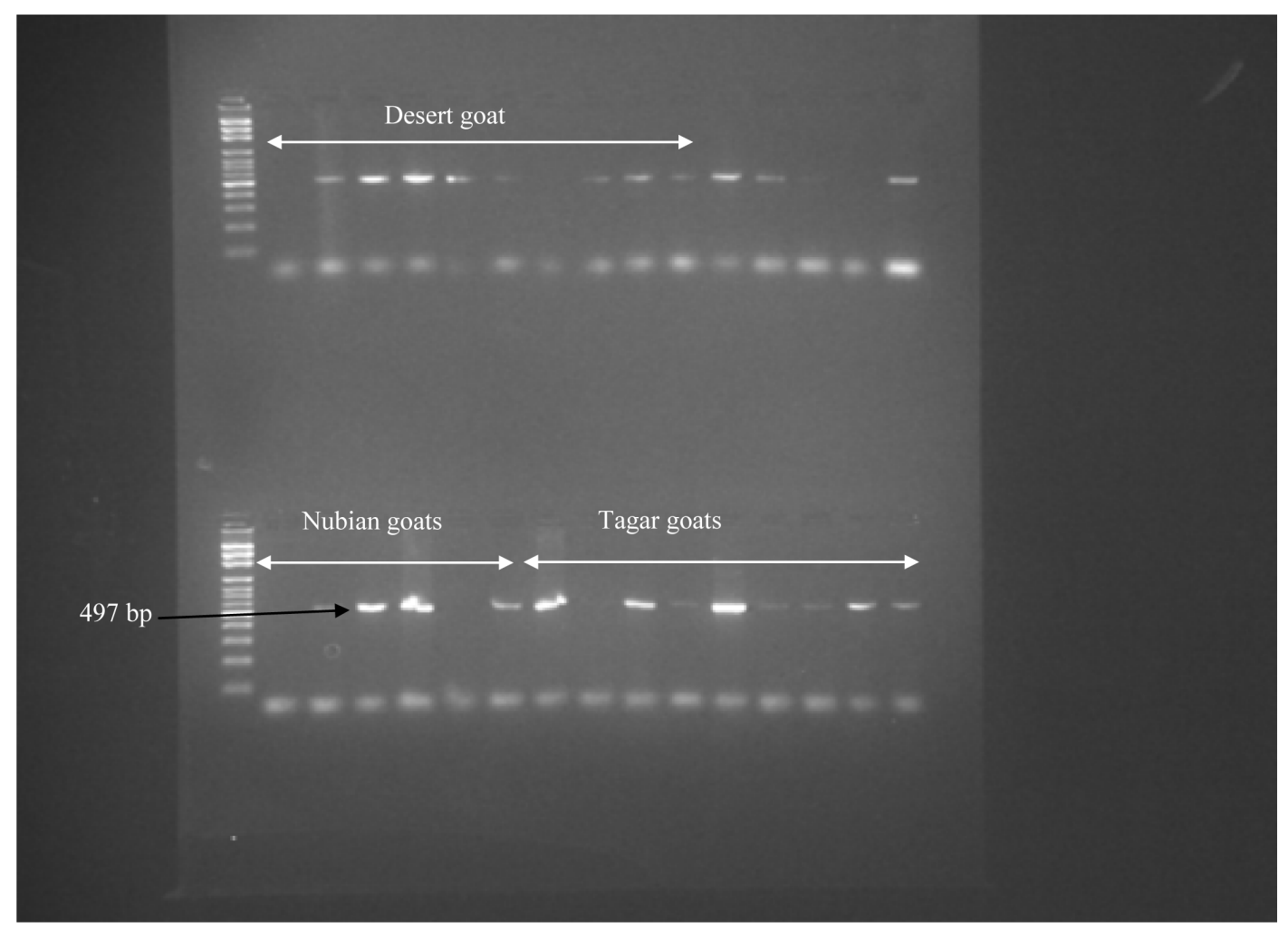

Figure 4. It shows the PCR products of the individuals of Desert, Nubian and Tagar goats. 


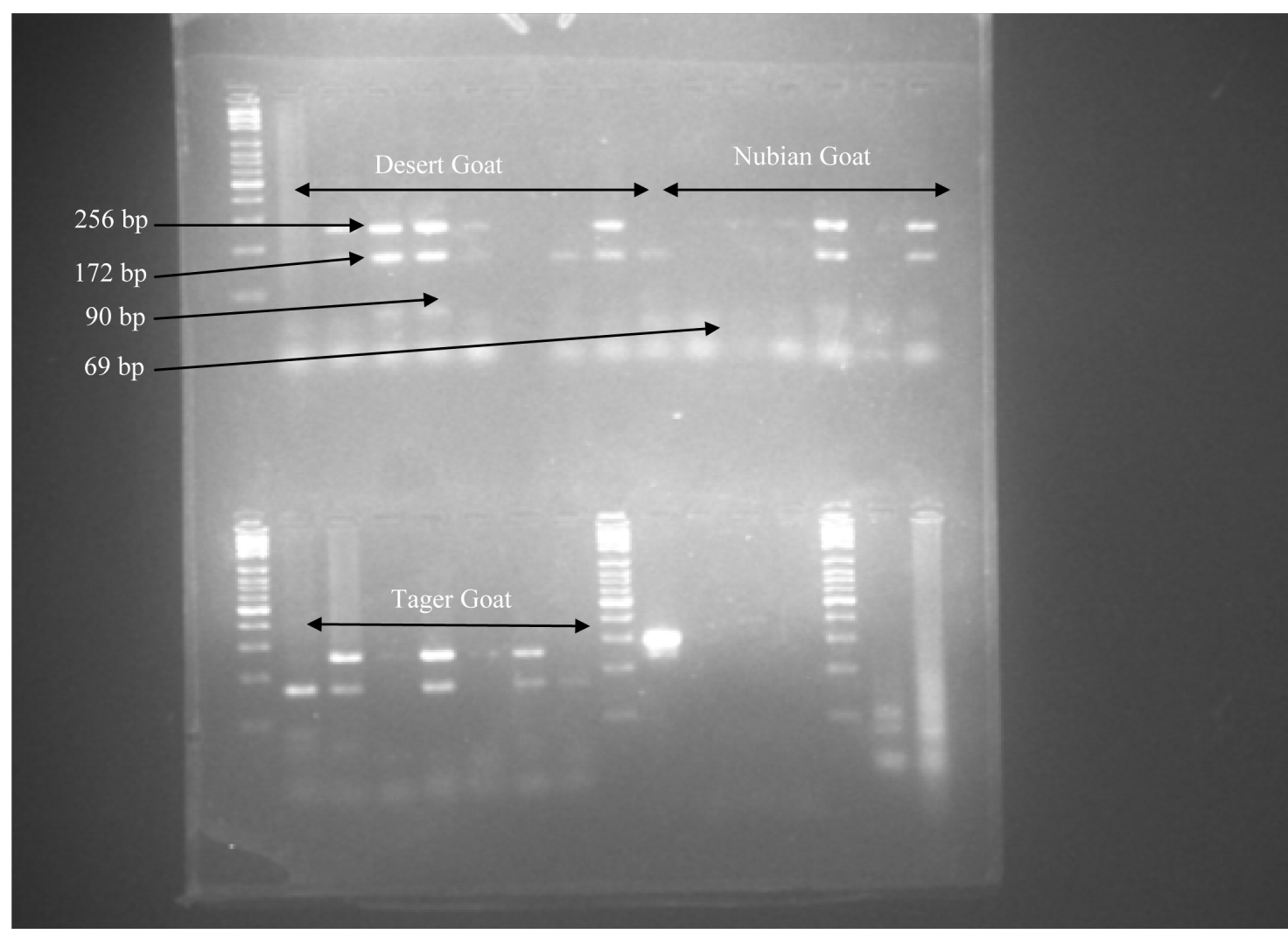

Figure 5. It shows the digeseted PCR products by restriction enzyme of the individuals of Desert, Nubian and Tagar goats.

\subsection{Lineage A (Haplotype A)}

Lineage A appeared with the band lengths 69 bp, 172 bp and 256 bP (Figure 5). The proportion of membership of individuals was 0.2 in Desert goat, 0.6 in Nubian goat and 0.6 in Tagar goat.

\subsection{Modified Lineage A}

Modified lineage A appeared with the bands length 90, 172, 256 bp and frequencies 0.2 of Desert goat, 0.2 of Nubian goat and 0.2 of Tagar goat (Figure 5).

\subsection{Samples that with Only Two Bands}

In these samples band 69 or band 90 bp were missing, band 172 and band 256 were present with frequencies of 0.3 in Desert goats, 0.3 in Nubian goats and 0.4 in Tagar goats (Table 1).

\subsection{Samples with No Bands}

In these samples, no bands appeared with frequencies of $0.2 \%$ in Desert goats, $0.1 \%$ in Nubian goats and $0.1 \%$ in Tagar goat breeds (Table 1).

\section{Discussion}

The work presented herein seems to show, for the first time, the substantial analysis of Sudanese goat breeds mt-DNA diversity. It also provides information about mt-DNA linages of goat breeds in the River Nile, South Kordfan and North Kordfan states, and thus, insights into their maternal genetic history. The present investigation states that most of the goat breeds studied belong to linage A which was recorded as 0.2 in Desert goats, 0.6 in Nubian and 0.6 in Tagar goat. This study aimed to detect Goat mitochondrial genetic diversity in two haplo- 
Table 1. It shows the products of the enzyme digestion in the individuals of Desert, Nubian and Tagar goats.

\begin{tabular}{ccccccc}
\hline The breed & Total number & Lineagee type (d) & Lineage type (a) & Modified lineag (a) & Sample with only two bands & Without bands \\
\hline Desert goats & 10 & 0 & 2 & 2 & 2 & 3 \\
Nubian goats & 10 & 0 & 6 & 2 & 3 & 1 \\
Tagar goats & 10 & 0 & 6 & 2 & 3 \\
\hline
\end{tabular}

types, A and D which resulted in individuals belonging to lineage A or modified lineage A and there was no individual belongs to lineage $\mathrm{D}$. The Population genetics theory actually predicts it is unlikely that two or more lineages will persist in a population beyond $4 N_{\text {ef }}$ generations ( $N_{\text {ef }}$ is the effective number of females) because genetic drift leads to monomorphism [25]. It is obvious that our result is in accord with this fact that the three Sudanese goat breeds persist beyond $4 N_{\text {ef }}$ generations. However, we did not find enough information when and how goat domestication in Sudan has taken place because the time of domestication suggested from the fossil record or by comparative wild local goat breeds. Archaeological studies suggest that the domestic goat Capra hircus was domesticated from the bezoar Capra aegagrus in the Fertile Crescent ([26] [27]). This origin was confirmed by genetic studies based on mitochondrial and nuclear DNA [28]. It is probably that Sudanese goat breeds came from fertile crescent as a result of people migration and traders. This suggestion was also mentioned by [10] who stated that the exchange and transportation of domestic animals has been related to human migration and trade which explains the present worldwide distribution of more than 300 different breeds of $C a$ pra hircus. However, the timing of the extensive movements in goats remains unknown [29].

Although the three Sudanese goat breeds under study are from different geographic areas, they belong to lineage A. [30] also claimed that more than $90 \%$ of goats solely from the A haplotype.

Our study highlighted the modification in haplotype A (Figure 2). This modification showed that the restriction enzyme cut the original band 497 bp (Figure 1) at 90 bp, 172 bp, 256 bp instead of 69 bp, 172 bp, 256 bp (Figure 2) as in lineage A. This is probably due to presence of new recognition point (catg) which appeared in our sequence as a result of insertion of new nucleotide or deletion of one nucleotide in individual from each breed with frequencies 0.2 of Desert goat, 0.1 of Nubian goat and 0.2 of Tagar goat. This modification may occur in advanced period of domestication and may be considered as a criterion of Sudanese goats breads.

The Mitochondrial DNA is commonly used for the study of domesticated species. The control region has been especially used for describing the genetic polymorphism of goats [20] because it is variable and structured enough across the geographical range of the species, and evolves at a constant rate [14]. Moreover, it allows maternal lineages to be followed and is less sensitive to introgression from wild species than nuclear DNA [20]. However individuals with modified lineage A observed in this study is due to mutation if we accepted the idea that all Sudanese goat breeds come to Sudan from fertile crescent following people migration and traders. Studies on nuclear genes are needed because they give information on gene flow and selection processes that had a great influence on the evolution of livestock species [14] and the breeds cannot be distinguished on the base of mtDNA ([31] [32]) while nuclear markers show a genetic structure [33]. It has become clear that in original area of domestication the individual genetic diversity should be noticed and at least more than one lineage should be present in animal breeds to be studied.

Two Sudanese goat breeds Desert and Tagar are raised beside cattle, camel and sheep by nomads. Mitochondrial DNA analysis raised Sudan as a contact zone between Asian and African ancestors of sheep which is expressed mainly in the existence of A haplotype in some individuals of Sudanese sheep and the results exposed the nomadic system as the main basis for keeping the biodiversity of sheep populations in Sudan [34]. According to this fact we expect that Sudanese goat breeds which are raised by nomads are good field of studying the domestic genetic potential and the history of goat domestication in Sudan (Divergent mtDNA lineages of goats in an Early Neolithic site, far from the initial domestication areas).

\section{Conclusion}

If we increase the animal population size concerning the geographic distribution and goat breed phenotypic characterization which were not done in this study due to lack of research centers for tager and Desert goat in their distribution regions so that population size and samples collection time depend on the return of nomads around 
cities in dry season which we expect to have general view on the history of their domestication and genetic make up of our domestic goat breeds. Some researchers tried to address this question, they analyzed mtDNA sequences from 19 ancient goat bones (7300 - 6900 years old) from one of the earliest Neolithic sites in southwestern Europe, the genetic diversity bears the molecular signature of past events, such as rapid demographic expansions. These has been largely studied across the old world (Europe, Asia, and more recently Africa). It is structured in six different haplogroups A, B, C, D, F and G [20] [22] [30]. Therefore, the study of this diversity helps to reconstitute the evolutionary history of the goat [14] and could bring new facts that help to understand the history of domestication.

Sultana et al. (2003) [24] state that the analysis of 44 mitochondrial DNA sequences from domestic goats identified a total of 129 mutations grouped into 38 haplotypes. In the present study beside the small population size of the samples, the results we obtained need further confirmative analysis to determine the sequencing of the PCR product and to find out whether the modification in lineage A is due to insertion or deletion of event in the modified linage A (0.2 Desert, 0.1 Nubian and 0.2 Tagar). In the context of Helena et al. (2006) [29] they analyzed mtDNA sequences from 19 ancient goat bones (7300 - 6900 years old) from one of the earliest Neolithic sites in southwestern Europe and found that the Phylogenetic analysis revealed that two highly divergent goat lineages coexisted in each of the two Early Neolithic layers of this site. This finding indicates that high mtDNA diversity was already present $>7000$ years ago in European goats, far from their areas of initial domestication in the Near East. According to these universal studies, this study is start step in Sudanese domestic goat breeds, that the DNA extraction, PCR product and enzyme digestion (two PCR-RFLP) methods.

To know whether the modified lineage A is a criterion of the Sudanese indigenous goat breeds or not, more and excessive analysis of the complete mtDNA D-loop and the cytochrome $b$ is necessary following the method of Sultana et al. 2003 [24]. Analysis of mitochondrial DNA sequencing from domestic goats is also needed to identify whether the mutations observed in five individuals is due to deletion or insertion events as well as the detection of the other two lineages $\mathrm{B}$ and $\mathrm{C}$ in the domestic goat breeds.

Some individuals from the different breeds in this study showed only two bands (with one band missing) and others appeared with no band. It is possible to attribute these abnormal features in these individuals to human error during sample collection and DNA extraction processing.

\section{Acknowledgements}

The authors want to thank all members of the unit of molecular biology and immunology-central laboratory for technical assistance.

Special thanks to the owners of goats for understanding of research importance.

\section{References}

[1] Acharaya, R.M. and Battasha, N.K. (1992) Status of Small Ruminant Research and Development. Proceeding of 5th International Conference on Goats (ICG', 92), New Delhi, 7-43.

[2] Ballal, K.M.E., Ahmed, M.-K.A. and Musa, L.M.A. (2008) Estimates of Phenotypic and Genetic Parameters of Growth Traits in the Sudanese Nubian Goat. Research Journal of Animal and Veterinary Sciences, 3, 9-14.

[3] Ministry of Animal Resources (2007) Statistical Bulletin for Animal Resources. Ministry of Animal Resources, Khartoum.

[4] Arab Organization for Agricultural Development (1990) Goat Resources in Arab state II. Sudan (in Arabic). Arab Organization for Agricultural Development (A.O.A.D), Printing Press, Khartoum.

[5] Arab Organization for Agricultural Development (2001) Arab Organization for Agricultural Development. Year Book of Agricultural Statistics. Arab Organization for Agricultural Development, Khartoum.

[6] FAO (1999) Production Year Book, Vol. 53. FAO Statistics Series. Food and Agriculture Organization of the United Nations, Rome.

[7] Devendra, C. and Mcleroy, G.B. (1982). Goat and Sheep Production in the Tropics. Longman, London, New York.

[8] Ismail, A.M., Yousif, I.A. and Fadlelmoula, A.A. (2011) Phenotypic Variations in Birth and Body Weights of the Sudanese Desert Goats. Livestock Research for Rural Development, 23.

[9] Bushara, I. and Abu Nikhaila, M.M.A.A.K. (2012) Productivity Performance of Taggar Female Kids under Grazing Condition. Journal of Animal Production Advances, 2, 74-79.

[10] Porter, V. (1996) G oats of the World. Farming Press, Ipswich. 
[11] Davis, S., Vigne, J.-D. and Buitenhuis, H. (1999) Les Premiers pas de la Domestication Animale à l’Ouest de l'Euphrate: Chypre et l'Anatolie Centrale. Paléorient, 25, 49-62. http://dx.doi.org/10.3406/paleo.1999.4686

[12] Peters, J., Helmer, D., von den Driesch, A. and Sana-Segui, M. (1999) Early Animal Husbandry in the Northern Levant. Paléorient, 25, 27-47. http://dx.doi.org/10.3406/paleo.1999.4685

[13] Wu, Y.P., Guan, W.J., Zhao, Q.J., He, X.H., Pu, Y.B., Huo, J.H., Xie, J.F., Han, J.L., Rao, S.Q. and Ma, Y.H. (2009) A Fine Map for Maternal Lineage Analysis by Mitochondrial Hyper Viable Region in 12 Chinese Goat Breeds. Journal of Animal Science, 80, 372-380.

[14] Bruford, W., et al. (2003) DNA Markers Reveal the Complexity of Livestock Domestication. Nature Review Genetics, 4, 900-910. http://dx.doi.org/10.1038/nrg1203

[15] Ajmone-Marsan, P., Garcia, J.F. and Lenstra, J.A. (2010) On the Origin of Cattle: How Aurochsbecame Domestic and Colonized the World. Evolutionary Anthropology, 19, 148-157. http://dx.doi.org/10.1002/evan.20267

[16] Larson, G., Dobney, K., Albarella, U., Fang, M.Y. and Matisoo-Smithet, A.L. (2005) Worldwide Phylogeography of Wild Boar Reveals Multiple Centers of Pig Domestication. Science, 307, 1618-1621.

[17] Joshi, M.B., Rout, P.K., Mandal, A.K., Tyler-Smith, C. and Singh, L., et al. (2004) Phylogeography and Origin of Indian Domestic Goats. Molecular Biology and Evolution, 21, 454-462. http://dx.doi.org/10.1093/molbev/msh038

[18] Sardina, M.T., Ballester, M., Marmi, J., Finocchiaro, R., van Kaam, J.B., et al. ( 2006) Phylogenetic Analysis of Sicilian Goats Reveals a New mtDNA Lineage. Animal Genetics, 37, 376-378. http://dx.doi.org/10.1111/j.1365-2052.2006.01451.x

[19] Tapio, M., Marzanov, N., Ozerov, M., Cinkulov, M. and Gonzarenko, G., et al. (2006). Sheep Mitochondrial DNA Variation in European, Caucasian, and Central Asian Areas. Molecular Biology and Evolution, 23, 1776-1783. http://dx.doi.org/10.1093/molbev/msl043

[20] Sultana, S., Mannen, H. and Tsuji, S. (2003) Mitochondrial DNA Diversity of Pakistani Goats. Animal Genetics, 34, 417-421. http://dx.doi.org/10.1046/j.0268-9146.2003.01040.x

[21] Fernandez, H., Hughes, S., Vigne, J.D., Helmer, D. and Hodgins, G., et al. (2006). Divergent mtDNA Lineages of Goats in an Early Neolithic Site, Far from the Initial Domestication Areas. Proceedings of the National Academy of Sciences of the United States of America, 103, 15375-15379. http://dx.doi.org/10.1073/pnas.0602753103

[22] Pereira, F., Queiros, S., Gusmao, L., Nijman, I.J. and Cuppen, E., et al. ( 2009) Tracing the History of Goat Pastoralism: New Clues from Mitochondrial and Y Chromosome DNA in North Africa. Molecular Biology and Evolution, 26, 2765-2773. http://dx.doi.org/10.1093/molbev/msp200

[23] Luikart, G., Gielly, L., Excoffier, L., Vigne, J.D. and Bouvet, J., et al. (2001) Multiple Maternal Origins and Weak Phylogeographic Structure in Domestic Goats. Proceedings of the National Academy of Sciences of the United States of America, 98, 5927-5932. http://dx.doi.org/10.1073/pnas.091591198

[24] Naderi, S., Rezaei, H.R., Taberlet, P., Zundel, S., Rafat, S.A., Naghash, H.R., Elbarody, M.A.A., Ertugrul, O. and Pompanon, F. (2007) Large-Scale Mitochondrial DNA Analysis of Thedomestic Goat Reveals Six Haplogroups with High Diversity. PLoS ONE, 2, 1012.

[25] Neigel, J.E. and Avise, J.C. (1986) In: Nevo, E. and Karlin, S., Eds., Evolutionary Processes and Theory, Academic, New York, 515-534.

[26] Manceau, V., Despres, L., Bouvet, J. and Taberlet, P. (1999) Systematics of the Genus Capra Inferred from Mitochondrial DNA Sequence Data. Molecular Phylogenetics and Evolution, 13, 504-510.

http://dx.doi.org/10.1006/mpev.1999.0688

[27] Henry, M.R. (1996) The Origins and Spread of Agriculture and Pastoralism in Northwestern South Asia. In: Harris, D.R., Ed., The Origins and Spread of Agriculture and Pastoralism in Eurasia, Smithsonian Institution, Washington DC, 390-412.

[28] Pidancier, N., Jordan, S., Luikart, G. and Taberlet, P. (2006) Evolutionary History of the Genus Capra (Mammalia, Artiodactyla): Discordance between Mitochondrial DNA and Y-Chromosome Phylogenies. Molecular Phylogenetics and Evolution, 40, 739-749. http://dx.doi.org/10.1016/j.ympev.2006.04.002

[29] Fernandez, H., Hughes, S., Vigine, J.-D., Helmer, D., Hodgins, G., Miquel, C., Hanni, C., Lukart, G. and Taberiet, P. (2006) Divergent mtDNA Lineages of Goats in an Early Neolithic Site, Far from the Initial Domestication Areas. Proceedings of the National Academy of Sciences of the United States of America, 103, 15375-15379. http://dx.doi.org/10.1073/pnas.0602753103

[30] Naderi, S., Rezaei, H.R., Pompanon, F., Blum, M.G. and Negrini, R., et al. (2008) The Goat Domestication Process Inferred from Large-Scale Mitochondrial DNA Analysis of Wild and Domestic Individuals. Proceedings of the National Academy of Sciences of the United States of America, 105, 17659-17664. http://dx.doi.org/10.1073/pnas.0804782105 
[31] Chen, S.Y., Su, Y.H., Wu, S.F., Sha, T. and Zhang, Y.P. (2005) Mitochondrial Diversity and Phylogeographic Structure of Chinese Domestic Goats. Molecular Phylogenetics and Evolution, 37, 804-814. http://dx.doi.org/10.1016/j.ympev.2005.06.014

[32] Amills, M., Capote, J., Tomas, A., Kelly, L. and Obexer-Ruff, G., et al. (2004) Strong Phylogeographic Relationships among Three Goat Breeds from the Canary Islands. Journal of Dairy Research, 71, 257-262. http://dx.doi.org/10.1017/S0022029904000342

[33] Pariset, L., Cappuccio, I., Ajmone Marsan, P., Dunner, S. and Luikart, G., et al. (2006) Assessment of Population Structure by Single Nucleotide Polymorphisms (SNPs) in Goat Breeds. Journal of Chromatography B-Analytical Technologies in the Biomedical and Life Sciences, 833, 117-120. http://dx.doi.org/10.1016/j.jchromb.2006.01.011

[34] Nahid Gornasa, B., Weimanna, C., El Hussienb, A. and Erhardta, G. (2010) Genetic Characterization of Local Sudanese Sheep Breeds Using DNA Markers. Small Ruminant Research. www.elsevier.com/locate/smallrumres 